\title{
MPP1 Gene
}

National Cancer Institute

\section{Source}

National Cancer Institute. MPP1 Gene. NCI Thesaurus. Code C24609.

This gene plays a role in cell proliferation, cytoskeletal modeling and intercellular communication. 